\title{
The Development of Teaching Media Based on PREZI Zooming Presentation on Heat and Temperature Subjects
}

\author{
Sri Hartini, Misbah, Ida Ariyani \\ Physics Education Program, Faculty of Teacher Training and Education \\ Universitas Lambung Mangkurat \\ Banjarmasin, Indonesia \\ srihartinippis@unlam.ac.id
}

\begin{abstract}
Both teachers and students have become numb to conventional classroom presentations, where they are confronted with slide after slide containing too much information in quick, disjointed succession. Prezi's zooming presentation opens up the classroom to active learning and interactivity, making lessons understandable, memorable, and fun. It causes the researchers to be interested to develop teaching media based on Prezi zooming presentation. This study aimed to describe the validity, the practicality, and the effectiveness of the teaching media. This study was a research and development which refers to the 4-D model. The subjects of the tryout were students of a class $X$ of SMAN 9 Banjarmasin. The results showed that (1) the validity of the teaching media was at valid category, (2) the practicality of the teaching media was at very good category, and (3) the effectiveness of the teaching media was at high category. It can be concluded that Prezi media is eligible to use in the learning process.
\end{abstract}

Keywords-Teaching Media, Prezi, Zooming Presentation, Heat and Temperature

\section{INTRODUCTION}

One key to the success of Indonesian development is education. Based on the Law of the Republic of Indonesia No. 20 Year 2003 on National Education System Article 1 Verse 20, Government Regulation on National Education Standards. Through education should be established. Everybody is expected to improve the quality of his/her presence in participating to support the development. Learning is one of the aspects of education which is involved in improving the quality of the individual. Besides teachers, teaching materials, and methods, the learning success is also influenced by the employed media. Appropriate choice of instructional media is a major factor in optimizing learning outcomes. The use of inappropriate media to students' conditions would lead to nonfunctioning of media optimally. Teachers should be able to create an atmosphere in the teaching and learning interactions so that it motivates them to learn well and seriously.

Media in the learning process can be used to clarify the abstract material that can be visualized by the appearance of the presentation. The media is used in order to make the teaching materials become more attractive and easily understood by students [1]. The use of media is indispensable in teaching and learning physics for many phenomena and natural phenomena that cannot be presented and understood by students without the media, such as the movement of objects. In general, the study of physics still uses conventional media (for instance blackboard and Over Head Projector/OHP). Along with the development of media and computers, conventional learning media are less attracted to students.

Based on the observations at SMA Negeri 9 Banjarmasin, the obtained results at that school were that it has complete facilities such as available and quite good internet networks, computer, and projector. These facilities are able of support the learning becomes easier and more efficient, yet the utilization is not optimal. This condition demands teachers as one element of education to improve and develop in accordance with the current development of science and technologies.

One of the ways to overcome the problem is to use Prezi media as a tool in the learning process. Using the interesting media is needed to make students more easily understand physics that requires motivation and innovation in teaching and learning process. This will make them not easily get bored while studying.

Prezi media presentation is a software to present, which is similar to PowerPoint. Prezi has other advantages such as Zooming User Interface (ZUI), which allows Prezi users be able to zoom in and out to see their presentation media with collaborative and attractive colors through the provided slides. Prezi is made of a canvas that is not limited by a frame that can be joined with a wide range of text, video, audio, and images that can be modified by pull, move, or turn left or right in order to look more attractive and unique without replacing the slide [2].

Prezi gives greater possibility to improve the learning process more effective and efficient, so that students' learning outcomes can be improved. Some of the benefits are that the use of Prezi media can make students more active [3] and can improve critical thinking skills [4]. The research conducted by [5] states that Prezi is a very attractive media used in the 
learning process. Also, Prezi can raise the students' motivation [6]. It also makes students' achievement improved [1].

Based on the description, the development of learning media named Zooming Presentation (Prezi) aimed to produce a decent media in the learning process. The specific objective of this study was to decribe validity, practicality, and effectiveness of Prezi as learning media.

\section{METHOD}

This study was a research and developmental research. This study used 4-D (Define, Design, Develop and Disseminate) development model. In this study, the media was developed using Zooming Presentation in tenth grade of senior high school on second semester about Temperature and Heat.

The subjects were tenth grade students at SMA Negeri 9 Banjarmasin in the academic year 2015/2016. The study was conducted in January to July 2016. The study was located at SMAN 9 Banjarmasin.

This instructional media was tested in the early stages using pre-test and post-test group [7]. It was tested using the following steps:

$$
O_{1} \times O_{2}
$$

Where : $O_{1}=$ pretest, $\times=$ learning process using Prezi based, $\mathrm{O}_{2}=$ posttest.

The instruments used in the study were in the form of validation sheet of Prezi instructional media, observation sheet for teacher activity and achievement test. The data analysis techniques in research and development were as follows: an instrument has validity if the results meet certain criteria (correlates between the measurement results with these criteria). The way to know the correlation is by correlating measurement results with the specified criteria. Some criteria were used as a benchmark to judge the validity of an instrument. Correlation technique used to determine the alignment is by the standard deviation of the correlation product moment technique. Then, it was adjusted to the criteria validation aspects of media.

$$
r_{x y}=\frac{\sum x y}{\sqrt{\left(\sum x^{2}\right)\left(\sum y^{2}\right)}}
$$

Where $r_{x y}=$ the correlation coefficient between $\mathrm{X}$ variable and $\mathrm{Y}$ variable, two variables that is correlated; $\sum x y=$ the number of multiplications $\mathrm{x}$ and $\mathrm{y} ; x^{2}=$ squares of $\mathrm{x} ; y^{2}=$ squares of $y$.

The interpretation of correlation coefficient $r_{x y}$ was done by comparing the results of the calculation of $r_{x y w}$ with the value of $r_{x y}$ in the table of the critical value $r_{x y}$ product moment. If the value of $r_{x y}$ is more than or equal to $r_{x y}$ table $\left(r_{h} \geq r_{t}\right)$, it means the correlation is significant, which means that the test instrument can be said to be valid. While, if the value $r_{x y}$ is less than $r_{x y}$ table $\left(r_{h} \geq r_{t}\right)$, it means the correlation is not significant, which means that test instrument is invalid. The value of $r_{x y}$ table can be seen on the table of values $r$ product moment [8].
The practicality of media can be measured through the teacher activities observation sheet which contains the steps that the teachers have done. The teacher activities observation sheet was observed to assess the average score $\bar{X}$ each time in a meeting by using the equation 4 .

$$
\bar{X}=\frac{\sum_{i=1}^{n} X_{i}}{n}
$$

Where $\bar{X}=$ average score, $X_{i}=$ the $\mathrm{i}$ informed score, and $n=$ the total of questions

Then, the average score was converted into qualitative data. The criteria of scoring of teacher activities observation sheet can be seen on Table 1 [8].

TABLE 1 THE CATEGORY of TEACHER ACTIVITIES

\begin{tabular}{|c|c|c|}
\hline Formula & Average Score & Classification \\
\hline$X>\bar{X}_{1}+1,8 \times s b_{i}$ & $\bar{X}>3.4$ & Very good \\
\hline $\bar{X}_{1}+0,6 \times s b_{i}<X \leq \bar{X}_{1}+1,8 \times s b_{i}$ & $2.8<X \leq 3.4$ & Good \\
\hline $\bar{X}_{1}-0.6 \times s b_{i}<X \leq \bar{X}_{l}+0.6 \times s b_{i}$ & $2.2<X \leq 2.8$ & Good enough \\
\hline $\bar{X}_{l}-1.8 \times s b_{i}<X \leq \bar{X}_{1}-0,6 \times s b_{i}$ & $1.6<\bar{X} \leq 2.2$ & Less good \\
\hline$X \leq X_{1}-1.8 \times s b_{i}$ & $\bar{X} \leq 1.6$ & Very less good \\
\hline
\end{tabular}

Where: $\overline{X_{a}}=1 / 2$ (ideal maximum score + ideal minimum score), $s b_{i}=1 / 6$ (ideal maximum score-ideal minimum score), and $X=$ empirical score.

The observation was done by two observers so that the reliability of teacher activities observation could be calculated with this following equation 5 .

$$
K K=\frac{2 S}{N_{1}+N_{2}}
$$

where: $k K=$ coefficient of agreement, $s=$ agreement, the number of same codes to the same object, $N_{1}=$ the total codes from first observer, and $\mathrm{N}_{2}=$ the total codes from second observer.

The coefficient of agreement (KK) was used to determine the tolerance of observations with observation reliability testing techniques. After calculating the reliability using the coefficient of agreement, we could determine the category of a media through interpretation of the value of correlation coefficient (r). Value interpretation of the correlation coefficient (r) can be seen in Table 2 [7].

TABLE II THE INTERPRETATION OF VALUE OF R

\begin{tabular}{|l|c|}
\hline The amount of $\mathbf{r}$ & Interpretation \\
\hline $0.800 \mathrm{~s} / \mathrm{d} 1.00$ & High \\
$0.600 \mathrm{~s} / \mathrm{d} 0.800$ & Moderate \\
$0.400 \mathrm{~s} / \mathrm{d} 0.600$ & Rather low \\
$0.200 \mathrm{~s} / \mathrm{d} 0.400$ & Low \\
$0.000 \mathrm{~s} / \mathrm{d} 0.200$ & Very low \\
\hline
\end{tabular}

Effectiveness of learning was measured through achievement test by doing pretest and posttest. Equation 6 is a normalization gain test used to calculate the value of students' cognitive learning outcome [9]. 


$$
<g>=\frac{\%<G>}{\%<G>\max }=\frac{(\%<S f>-\%<S i>)}{(100-\%<S i>)}
$$

Categories of effectiveness of learning process can be seen on Table 3 [9].

TABLE III. CATEgories of EFFeCtiveness of LEARNing PRocess

\begin{tabular}{|r|c|c|}
\hline No & Score & Criteria \\
\hline 1 & $\langle\mathrm{~g}\rangle \geq 0.7$ & High \\
\hline 2 & $0.7\rangle\langle\mathrm{g}\rangle \geq 0.3$ & Moderate \\
\hline 3 & $\langle\mathrm{~g}\rangle\langle 0.3$ & Low \\
\hline
\end{tabular}

\section{RESULT AND DISCUSSION}

The validation of the instructional media was done by the expert validators from an academician and a practitioner.

Table IV The Result of Validity on Teaching Media

\begin{tabular}{|l|c|c|}
\hline \multirow{2}{*}{ Aspect } & \multicolumn{2}{|c|}{ Validation Score } \\
\cline { 2 - 3 } Variations of Presentation & $\boldsymbol{X}$ & $\boldsymbol{Y}$ \\
\hline \multirow{3}{*}{ Observation Enforceability } & 3 & 3 \\
\cline { 2 - 3 } & 3 & 3 \\
\cline { 2 - 3 } & 3 & 3 \\
\hline \multirow{2}{*}{ Completeness of Media } & 4 & 3 \\
\hline \multirow{2}{*}{ Design of Media } & 3 & 3 \\
\hline Completeness of Display & 4 & 3 \\
\hline Total & 4 & 4 \\
\hline Average & 3 & 3 \\
\hline The Value of rxy & 3.3 & 32 \\
\hline Category & \multicolumn{2}{|c|}{ Valid } \\
\hline
\end{tabular}

Table 4 shows that the results of the validation analysis of instructional media that covers aspects of assessment of variations in the presentation, enforceability, completeness of media, media design, and overall appearance were at very well category. Based on the validation results, the developed instructional media was categorized valid.

Prezi is a presentation of visual design that is very fun and makes the presentation is interesting. Audiences are interested and focused to the presentation. Prezi is one tool that is used to keep classes interesting and interactive [10]. Based on the results of the validation, all aspects of instructional media have been fulfilled. This suggests that learning media can be used in learning. A valid product means the product can be used to measure what should be measured [11].

The practicality of the instructional media was measured from the observation sheet of teacher activities observation. The observation sheet of teacher activities was developed based on standards and basic competencies which become indicators and learning objectives which were based on education level in the 2006 curriculum.

TABle V. The analysis Results OF the Average OF Teacher ACTIVITIES FROM OBSERVATION IN EACH MEETING

\begin{tabular}{|c|c|c|}
\hline Meeting & Average in each meeting & Reliability \\
\hline I & 3.65 & 0.80 \\
\hline II & 3.73 & 0.85 \\
\hline III & 3.70 & 0.90 \\
\hline Total & 11.08 & 2.55 \\
\hline Average & 3.69 & 0.85 \\
\hline Category & Very good & High \\
\hline
\end{tabular}

The observations of teacher's activities were conducted in three meetings. The first meeting was about heat material, the second meeting was about Black principles, and the third meeting was about heat transfer. The observation results of the teacher activities were 3.69 each meeting which was included in very good category. The first meeting was 3.65 and categorized as very good, the second meeting was 3.73 and categorized very good, and the third meeting was 3.70 and categorized as very good. The reliability value was 0.85 that was categorized as high reliability. Teachers' activities that were observed had consistency and stability in measuring the practicality of the developed instructional media. A product is said to be practical if the product can be used and the product is said to be effective if the results are in accordance with the objectives set in the development [12]. If practically and theoretically learning media can be applied in the class, it means that the media is categorized as good [13].

Learning with Prezi as instructional media Prezi really helps teachers in the learning process. Prezi learning media can help learning activities run smoothly, students become more active and inovatif. The use of media as a tool in the learning process makes teachers explain more easily, especially in presenting concrete examples in everyday life. It is appropriate with the function of media to overcome the limitations of space and time and energy and passion. Also, it can increase students' motivation in learning, as well as more direct interaction between students with the resources that are used in the learning process [14].

The effectiveness of instructional media was measured through achievement test. Student learning outcomes in this study were taken through pre-test and post-test. Table 6 shows the value of learning outcomes calculated using normality gain test.

Table Vi. Gain Calculation Test

\begin{tabular}{|c|c|c|}
\hline Total of Students & Average of Gain & Category \\
\hline 36 & 0.73 & High \\
\hline
\end{tabular}

The effectiveness of teaching media based on test results was categorized high. It was also because the implementation of teacher activity observation sheet which was done properly and systematically. If the teacher activity is implemented 
properly and systematically, it means that all learning objectives in the lesson plan are also conveyed properly. If the learning objectives have been performed well, the value of learning effectiveness that was measured through achievement test would also be good. This is because the used achievement test was set based on learning objectives in the lesson plan. The effectiveness is based on different levels of experience and the results of interventions are consistent with the purposes[13]. The effectiveness refers to the achievement of a goal. A product will be effective if the product can facilitate the achievement of students' learning outcomes in accordance with the standard score minimum decided by school [15].

Based on the validity, practicality, effectiveness results in this study, Prezi is worth using. This is the same as the general purpose of media, such as to make clear a message that is not too verbalistis, provide stimulus as well as the same motivation so it can stimulate attention, interest, thought, and students feeling in learning to achieve the objectives [14]. Therefore, using Prezi in the process of learning can enhance students' creativity [16]. The learning process can motivate students to be active and creative, can improve the imagination of students, can clarify the complex materials, and can reveal the material or object that cannot be displayed directly so that learning becomes innovative and fun. The application of Prezi, the zooming media presentations, on physics subject can give a significant impact on improving student learning outcomes [17]. An increase in levels of cognitive students who use the zooming presentation media in the learning process [2]. There is a huge increasing is students learning outcomes after using Prezi learning media [18].

\section{CONCLUSION}

Based on the results of this research and development, it was acquired that: (1) the validity of Prezi media based in teaching is categorized as valid; (2) the practicality of Prezi is categorized as very good; (3) the effectiveness of Prezi media based in teaching is high. Based on the results of validity, practicality, and effectiveness, we can conclude that Prezi media based in teaching on the subject of temperature and heat is worth using.

\section{ACKNOWLEDGMENT}

This research was supported by Universitas Lambung Mangkurat (DIPA fund 2016). The authors thank to the headmaster of SMAN 9 Banjarmasin for the research permission at the school.

\section{REFERENCES}

[1] E. W. Wibowo, "Analisis pemanfaatan prezi desktop sebagai media pembelajaran di IAIN Sultan Maulana Hasanuddin Banten”, Primary, 8(02), pp 147-160, 2017.

[2] P. Z. Zannah, D. Mulhayatiah, F. Alatas, "Penggunaan media pembelajaran zooming presentation untuk meningkatkan hasil belajar siswa kelas x pada konsep suhu dan kalor", EDUSAINS, 6(2), pp 211216, 2014.

[3] Anjar Miska Prayoga. "Penggunaan media prezi dan metode pembelajaransnowball throwing untuk meningkatkan prestasi belajar akuntansi”, Jupe UNS, vol. 1, No. 2, pp.1-8, 2012.

[4] Muhammad Yusuf Rodhi dan Wasis. "Pengembangan media pembelajaran berbasis prezi untuk meningkatkan keterampilan berpikir kritis pada materi kalor", Jurnal Inovasi Pendidikan Fisika (JIPF), vol. 03 No. 02,pp 137-142, 2014.

[5] E. Epinur, S. Wilda, A. Adriyani, "Pengembangan media pembelajaran kimia pada materi elektrokimia untuk kelas XII SMA N 8 Kota Jambi dengan menggunakan software Prezi", Journal of The Indonesian Society of Integrated Chemistry, 6(1), 2014.

[6] I. J. Saputri, D. T. Irafahmi, S. Sumadi, "Media presentasi prezi pada mata pelajaran akuntansi untuk meningkatkan motivasi belajar siswa", Journal of Accounting and Business Education, 2(4), 2016.

[7] S. Arikunto, Prosedur Penelitian Suatu Pendekatan Praktik Edisi Revisi VI. Jakarta: Rineka Cipta, 2006.

[8] Widoyoko. Evaluasi Program Pembelajaran. Yogyakarta: Pustaka Pelajar, 2013.

[9] R. R. Hake, "Analyzing Change/Gain Score”. Departement of Physics Indiana University, 1998, unpublished

[10] Nora Strasser, Using Prezi In Higher Education, The Clute Insitute International Academic Conference, Breakenridge, Colorado USA, 2013.

[11] Sugiyono, Metode Penelitian Kualitatif Kuantitatif dan R\&D. Bandung: Alfabeta, 2013.

[12] Hamdani, Strategi Belajar Mengajar, Bandung: Pustaka Setia, 2011.

[13] J. V. Akker, Principles anD Methods of Development Research. Design Approaches and Tools in Education and Training. (pp. 125-136). Dodrecht: Kluwer Academic Publisher, 1999.

[14] Daryanto, Media Pembelajaran, Jakarta: Gava Media, 2013.

[15] W. Safutri, "Efektivitas Pelaksanaan Pemberdayaan Masyarakat Melalui Program Penguatan Keluarga Oleh Yayasan Sos Children's Village Medan di Lingkungan III Kelurahan Namo Gajar Kecamatan Medan Tuntungan”, Skripsi Universitas Sumatera Utara, 2013, unpublished

[16] S. Suryani, K. Khairil, C. Nurmaliah, "Penggunaan media Prezi pada materi sistem peredaran darah manusia untuk meningkatkan kreativitas peserta didik SMA NEGERI 1 Lhoksukon", Jurnal Edubio Tropika, 3(1), 2015.

[17] D. Melida, D, "Pengaruh media Prezi the zooming presentations terhadap hasil belajar fisika siswa kelas XI SMA N 12 Padang", Pillar of Physics Education, 4(2), 2014.

[18] Y. Antika, B. Suprianto, "Pengembangan media pembelajaran berbasis prezi sebagai upaya meningkatkan hasil belajar siswa kompetensi dasar aplikasi rangkaian OP AMP mata pelajaran Rangkaian Elektronika Di SMK Negeri 2 Bojonegoro", Jurnal Mahasiswa Teknologi Pendidikan, 5(2), 2016. 